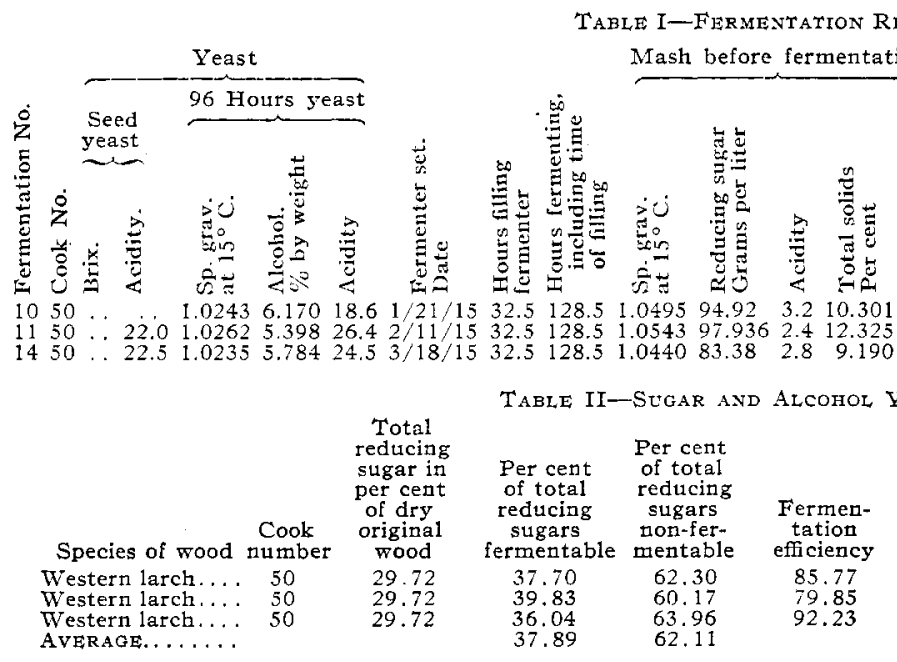

Schorger, of this laboratory, has analyzed both of these woods with the following results:

\begin{tabular}{|c|c|c|c|}
\hline & TESTERN IA & WhITE SP & ZUCE \\
\hline & $\begin{array}{l}\text { (Base) } \\
\text { Per cent }\end{array}$ & Per cent & $\begin{array}{l}\text { (4 Samples) } \\
\text { Average }\end{array}$ \\
\hline & 9.75 & 0.90 to 1.95 & 1.36 \\
\hline Solut & $\begin{array}{l}14.47 \\
16.52\end{array}$ & $\begin{array}{l}0.82 \text { to } 1.45 \\
1.88 \text { to } 2.52\end{array}$ & $\begin{array}{l}1.12 \\
2.14\end{array}$ \\
\hline $\begin{array}{l}\text { cent } \mathrm{NaOH}, 1 \\
\ldots \ldots \ldots \ldots\end{array}$ & 32.72 & 6.72 to 8.84 & 7.70 \\
\hline $\begin{array}{l}\text { Soluble in } 1 \text { per cent } \mathrm{NaOH}, 6 \\
\text { min heating }\end{array}$ & 50 & 11. & 12.21 \\
\hline Pent & .6. & 10.0 & 10.39 \\
\hline & 3 & 3.08 & \\
\hline & & 51.95 to 58. & 56 \\
\hline bh & $\begin{array}{l}0.84 \\
0.36\end{array}$ & 0.285 to 0.326 & 0.307 \\
\hline
\end{tabular}

It will be noticed that the larch contains a large amount of water-soluble material and a proportionally small amount of cellulose. In all cases, the above analyses were made on a fresh sample taken from the same lot. In a subsequent paper, Mr. Schorger will take up the composition of this water-soluble material, the chief constituent of which is a galactan which yielded approximately io to 12 per cent of the dry weight of the wood of galactose, which, in turn accounts for the high sugar yields obtained from the larch.

It has been suggested by Körner, ${ }^{1}$ although disputed by Gallagher and Pearl, ${ }^{2}$ that in the acid hydrolysis of cellulosecontaining material, the source of the fermentable sugars and, therefore, the alcohol, is the cellulose itself.

If the sugar yield for the larch is recalculated so that it is proportional to the cellu:ose content, assuming 22 per cent of sugar from the spruce, we would have then 16.7 per cent of sugar instead of 29.7 per cent, as actually obtained. However, as noted above, about io or 12 per cent of galactose was obtained, which subtracted from the total sugar yield of 29.7 per cent, would leave from 17.7 to 19.7 per cent of sugar comparable to that obtained from spruce. Under normal conditions, with a 94 per cent efficiency and a yield of that per cent of the theoretic amount of alcohol formed, which is 5 r. I per cent, we get for 60 or 65 per cent of total sugar fermentable the following alcohol yields:

$$
\begin{aligned}
& 16.7 \times 0.511 \times 0.94 \times 0.60=4.83 \text { per cent alcohol } \\
& 16.7 \times 0.511 \times 0.94 \times 0.65=5.23 \text { per cent alcohol }
\end{aligned}
$$

The actual alcohol yield is 4.977 per cent, which corresponds to about 62 per cent of total sugar fermentable, which is the average of the above figures chosen for spruce. It appears, therefore, that the yield of fermentable sugar and alcohol is proportional to the cellulose content of the wood, irrespective of other materials that may be contained therein. In addition, western larch butts will be a good raw material for the production

1 Zeitschrift für angewandie Chemie, 1908, 2353.

2 Proc. Eighth Intern. Cong. Appl. Chem., 13, p. 147. of ethyl alcohol if a yeast is found which will ferment the galactose as well as the dextrose within the time limit and other limitations as prescribed by the Bureau of Internal Revenue. This phase of the subject has been reserved and will be taken up in the near future.

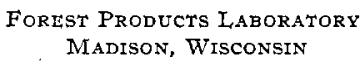

\section{THE APPLICATION OF THE DAVIS SPOT TEST IN THE PRELIMINARY EXAMINATION OF CREOSOTES}

\section{BY HOMER CLOUREY}

The tests undertaken and included in this report were run for the purpose of verifying the "absorption spot test" given in an article by T. H. Davis on "The Examination of Creosote,", and described in this article as follows:

"Absorption Spot-Allow six drops of the sample to fall from a burette upon the surface of clean, white blotting paper. If tar, carbon, or dirt is present, it is very easily observed, as it quickly segregates at the center. The paper should be laid away, in a flat position, for several hours, in a place free from dust. If then examined, foreign matter will be observed in a distinct zone at the center of the spot; the outer zone very readily indicates the character of the oil."

In order to establish some idea of the sensitiveness of this test for carbon and dirt in creosote and make it fairly quantitative a series of spots was made from a carbon-free creosote with definite graduated amounts of carbon in the form of lampblack added.

This series comprises six mixtures of creosote and lampblack as follows:

$\begin{array}{llllllll}\text { Per cent lampblack added........ } & 0.0 & 0.005 & 0.01 & 0.05 & 0.10 & 0.50\end{array}$

This series is shown in Fig. I. The results obtained show an increasing gradation in the density of the free carbon ring at the center and indicate that 0.005 per cent is easily shown by this test. In heavier percentages than 0.5 per cent, the amount in an unknown sample would be difficult to estimate by comparison.

The appearance of several authentic samples of various creosotes and oils used for wood-preserving purposes is shown in Fig. II. No. I shows coal tar creosote with the characteristic brown gradually shading on the edges to a lighter zone: if carbon and dirt are present, these are segregated in an inner circle which is the size of the original spot before diffusion. No. 2 is a characteristic water gas tar creosote with the large spot and outer yellow zone characteristic of this oil. No. 3 illustrates the character of the spot afforded by a paraffin base crude oil used for wood-preserving purposes: this is almost colorless

1 Oil, Paint, and Drug Reporter, February 14, 1910. 


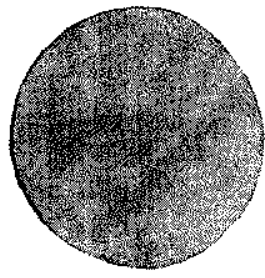

0.000

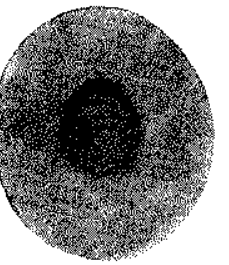

Coal Tar Creosote

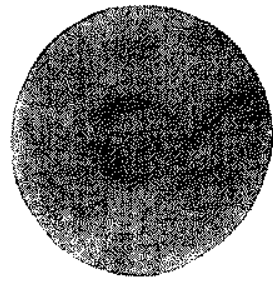

0.005

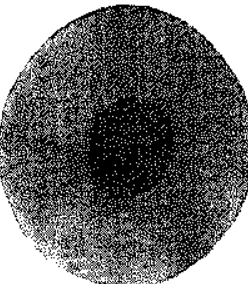

0.01

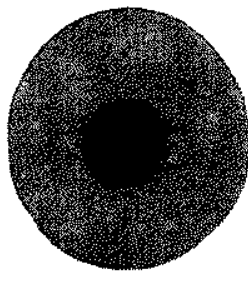

0.05

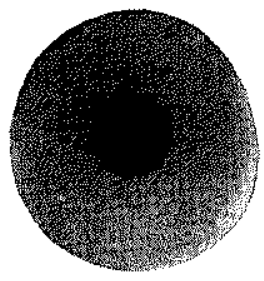

0.10

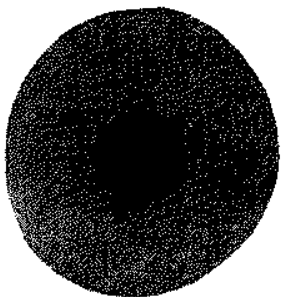

0.50

Reduced a little over one-half. Color-light brown with black centers

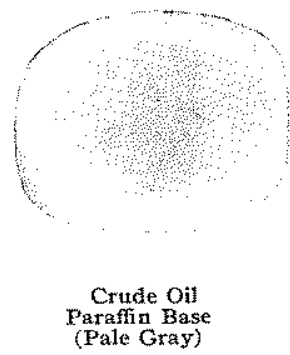

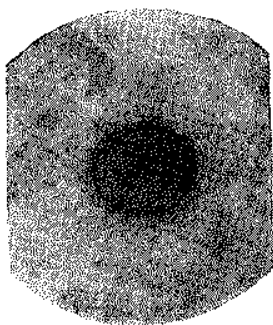
Water Gas Tar
Creosote (Brown and Black)

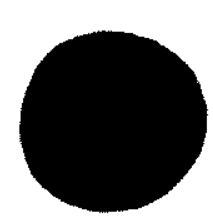

Water Gas Tar
Dark Brown)

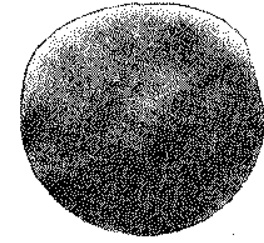

$$
\begin{gathered}
\text { Hardwood, Tar } \\
\text { Creosote }
\end{gathered}
$$$$
\begin{gathered}
\text { Creosote } \\
\text { (Dark Gray) }
\end{gathered}
$$

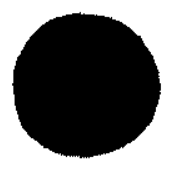

Coal Tar

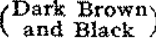

Fig. II-SPOTS OF VARIOUS OULS USED gOR WOOD PRESERVING

Reduced a little over one-half, Colors as noted

while an asphaltic base crude oil shows a browner center. No. 4 shows the characteristic dead gray-black of creosote made from hardwood tar. No. 5 is the even dark brown spot of a typical water gas tar: this tar is of ten used in creosote tar mixtures at the present time. No. 6 is the spot of a coal tar with the heavy carbon in the center and the small diffusion of the pitchy mass.

The spots given in Fig. II represent only the typical spots of the various oils used for wood-preserving purposes. In actual practice, these oils are used in more or less admixture with each other and a large number of spots can be obtained grading from one of these types to another.

The admixture of tar can be determined roughly from the size (smaller) and the getneral character of the spot. The heavy tar does not diffuse with the speed of the lighter creosote oils. CONCLUSIONS

I-The presence of dirt and free carbon in creosote oil is indicated in very minute quantities by this test.

II-If the creosote spot shows a dense black center it will probably be necessary to run a free carbon analysis to determine if the creosote passes the free carbon specification.

III - The various types of wood-preserving oils can be easily distinguished from each other by this test when they are true type samples.

IV-In the large number of intermediate or mixed commercial oils, the value of this preliminary test will depend on the experience of the one applying it together with the possession of a large number of authentic samples for comparison. On applying this test to a number of olls compounded from known authentic samples it was possible to tell the constituents with a reasonable degree of accuracy.

FOREST PRONUCTS LABOKA TORX

Madison, Wisconsin

\section{ISOPRENE FROM $\beta$-PINENE}

By A. W, Schorger AND R, SAYre

The discovery during the latter half of the past century of a close relation between isoprene, the terpenes, and caoutchouc has naturally directed considerable attention toward the utilization of the terpenes as a source of isoprene. This relation may be represented by the following reversible reactions:<smiles>C=C(C)C=CC1CC1C1CC2(C)CCC(C(=C)C)C(C2)C1C</smiles>

Dipentene $\rightleftarrows$ 2-Isoprene $\rightleftarrows$ (Dimethyl-1,5-Octadiene-1,5) (Caoutchouc)

It was to be expected that attempts would first be made to utilize $\alpha$-pinene as a raw material, since, in the form of turpentine, it can be more easily and cheaply obtained than any of the other terpenes. The results of former experiments clearly indicate, however, that only comparatively low yields are possible from turpentine. Tilden, ${ }^{1}$ by passing turpentine through a red-hot tube, obtained about $20 \mathrm{cc}$. of isoprene from a liter of turpentine. By means of his isoprene lamp, Harries ${ }^{2}$ obtained about I per cent of isoprene from commercial pinene and attributed even this small amount to the presence of dipentene in the turpentine employed. Herty and Graham ${ }^{3}$ obtained 5.5 per cent (by volume) of isoprene from turpentine and 8.0 per cent from a fraction boiling between $\times 55$ and $156^{\circ}$. These authors are of the opinion that the isoprene obtained from turpentine is not due to dipentene present in the turpentine as asserted by Harries, an opinion that we believe is fully justified.

Apparently the only terpene yielding considerable amounts of isoprene is limonene (dipentene). Harries ${ }^{2}$ obtained 30 to 50 per cent of isoprene from commercial linoneze while Herty and Graham obtained i 2 per cent from a limonene fraction. Staudinger and Klever found that by working at a pressure of about $4 \mathrm{~mm}$, a yield of 60 per cent of exceptionally pure isoprene could be obtained from limonene.

According to patents held by Schering and Company, ${ }^{5}$ con-

1 Chem. News, 46 (1882), 220.

2 Ann., 383 (1911), 228-9.

3 Tris jovrhad, 6 (1914), $803-4$

4 Ber., 44 (1911), 2212.

5 German Patent 260,934 ; K. Steplan, U. S. Patent $1,057,680$ (1913) (Assignor to Schering \& Co.). 